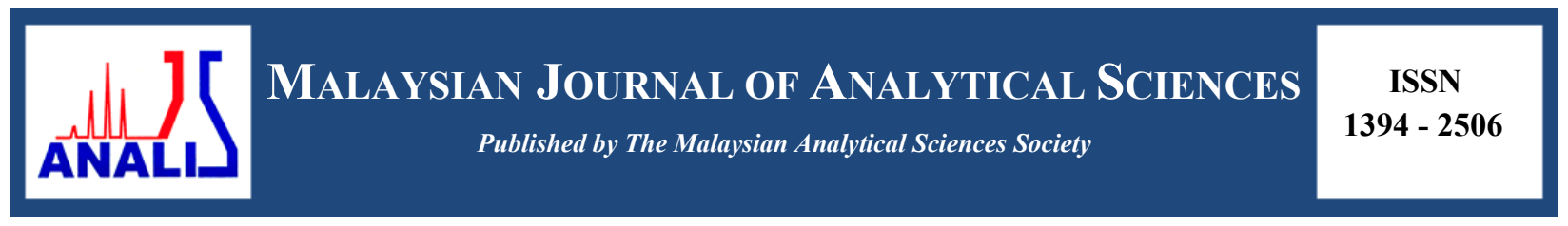

\title{
A STUDY OF MICROBE AIR LEVELS IN SELECTED ROOMS OF A HOSPITAL CULTIVATED ON TWO CULTURE MEDIAS
}

\author{
(Kajian Tahap Mikrob dalam Udara yang Di Kultur Pada Dua Media Kultur di dalam Bilik \\ Hospital Terpilih)
}

\author{
Che Noraini Che Hasnam ${ }^{1}$, Hafizan Juahir ${ }^{1 *}$, Azman Azid ${ }^{1}$, Mohammad Azizi Amran ${ }^{1}$, Fazureen Azaman ${ }^{1}$, Ahmad \\ Dasuki Mustafa $^{1}$, Zarizal Suhaili ${ }^{1}$, Sukri Md. Ismail ${ }^{1}$, Khairul Affendi Yusof ${ }^{2}$, Cik Fatimah Nadia Che Hasnam ${ }^{1}$ \\ ${ }^{1}$ East Coast Environmental Research Institute (ESERI), \\ Universiti Sultan Zainal Abidin, Gong Badak Campus, 21300 Kuala Terengganu, Terengganu, Malaysia \\ ${ }^{2}$ Faculty of Industrial Sciences and Technology, \\ Universiti Malaysia Pahang, Lebuhraya Tun Abdul Razak, 26300 Gambang, Kuantan, Pahang, Malaysia \\ *Corresponding author: hafizanj@unisza.edu.my
}

Received: 14 April 2015; Accepted: 3 August 2016

\begin{abstract}
The levels of airborne microbe in hospital are unknown previously in Terengganu. Typically, fungi and bacteria are usually presented in indoor environments and cause of human health effects. The aim of this descriptive study was to investigate the level of airborne microbial pollution in the indoor air of the selected hospital rooms. A total of 8 rooms were investigated for this study. Sampling was conducted with an Eco-Mas 100 Single-Stage Microbial Air Impactor and counting plates containing two selective media, Rose Bengal Chloramphenicol Agar (RBCA) and Sabouraud Dextrose Agar (SDA). Air sampling was taken for $5 \mathrm{~min}$ at an airflow rate of $28.3 \mathrm{~L} / \mathrm{min}$. A medium-low level of bacterial and fungal concentrations $\left(8\right.$ to $38 \mathrm{CFU} / \mathrm{m}^{3}$ for RBCA and 2 to $149 \mathrm{CFU} / \mathrm{m}^{3}$ for SDA), respectively were found in indoor air quality of the hospital. The highest microbe air levels for RBCA was measured in the washing room, while the highest microbe air levels for SDA was measured in the reprocessing room of hemodialysis unit. The culturable airborne bacterial and fungal concentrations on SDA agar were higher than those on RBCA. The most common culturable airborne microbes were Penicillium and Cladosporium. In addition, the use of RBCA rather than SDA significantly improved the fungal yield. The study also revealed that no indoor atmosphere in the hospital is completely free from microorganisms.
\end{abstract}

Keywords: hospital, indoor air quality, airborne microbe, colony counts

\section{Abstrak}

Tahap mikrob bawaan udara di hospital tidak di ketahui sebelum ini di Terengganu. Lazimnya, kulat dan bakteria terdapat dalam persekitaran dalaman dan menyebabkan kesan terhadap kesihatan manusia. Tujuan kajian deskriptif ini adalah untuk menyiasat tahap pencemaran mikrob bawaan udara di dalam bangunan bilik - bilik yang terpilih di hospital. Sejumlah 8 buah bilik telah disiasat untuk kajian ini. Pensampelan telah dijalankan dengan menggunakan Eco-Mas 100 Impaktor Udara Mikrob Tahap Tunggal dan plat yang mengandungi dua media terpilih iaitu Rose Bengal Chloramphenicol Agar (RBCA) and Sabouraud Dextrose Agar. Pensampelan udara dijalankan selama 5 minit pada kadar aliran udara $28.3 \mathrm{~L} / \mathrm{min}$. Satu tahap kepekatan sederhana rendah bakteria dan kulat ( 8 hingga $38 \mathrm{CFU} / \mathrm{m}^{3}$ untuk media RBCA dan 2 hingga $149 \mathrm{CFU} / \mathrm{m}^{3}$ untuk media SDA) masing - masing ditemui dalam kualiti udara dalam bangunan hospital tersebut. Tahap udara mikrob yang tertinggi untuk RBCA diukur di bilik cuci, manakala tahap udara mikrob yang tertinggi untuk SDA diukur di bilik pemprosesan semula unit hemodialisis. Kepekatan bakteria dan kulat bawaan udara yang dikultur pada agar SDA adalah lebih tinggi daripada agar RBCA. Mikrob bawaan udara lazimnya yang didapati dari media kultur ialah Penicillium and Cladosporium. Penggunaan media RBCA adalah ketara lebih baik berbanding media SDA dalam penghasilan kulat. Kajian juga mendedahkan bahawa tiada keadaan persekitaran tertutup di dalam hospital yang bebas sepenuhnya dari mikroorganisma. 


\section{Che Noraini et al: A STUDY OF MICROBE AIR LEVELS IN SELECTED ROOMS OF A HOSPITAL CULTIVATED ON TWO CULTURE MEDIAS}

Kata kunci: hospital, kualiti udara dalam bangunan, mikrob bawaan udara, pengiraan bilangan koloni

\section{Introduction}

Indoor air quality resulting from high levels of fungi (mold) and bacteria become a critical issue in the world and are therefore ubiquitous [1]. This is because of people spend most of their time indoors which is about 90 percent exposure to many types of pathogens $[2,3,4]$. Recently, an increasing number of people have experienced adverse health effects because of their indoor environments like infections, toxic reactions and hypersensitivity pneumonitis $[5,6,7]$. This is due to indoor microbial exposure has been related to a range of serious public health hazard and well-being of the population [8].

Hospital is an important facility of public place associated with the environmental exposure of humans. Besides, hospital is referred as a special public place [9]. In addition, the number of people is much higher in hospital every day compared to other public places. The effect of hospital in indoor air quality to humans is more significant, therefore this study has forwarded because there are very little studies that focused on the indoor airborne microbial in hospital in Malaysia especially in Terengganu. Fungi are common in indoor environments and about $10 \%$ of people have affected with fungal allergy like allergic bronchitis, chronic obstructive pulmonary disease and asthma $[1,10]$. Therefore, the airborne in indoor environment of the hospital is essential for the health of patients and medical personnel.

The culturable methods are still widely used generally with impactors and it is a sterile method [11]. The plates have been put in the impactor and grows as a colony, it is then counted as a colony-forming unit, or CFU [12]. This method is easy to implement and low cost thus reproducing the most common culturable conditions regarding total airborne microbial from a particular procedure [13]. According to study by Pasquarella et al. [14], bacterial levels less than $39 \mathrm{CFU} / \mathrm{dm}^{2} / \mathrm{h}$ with passive sampling were considered as acceptable values for the air microbial contamination. While the recommended maximum limits set by the American Conference of Governmental Industrial Hygienists with the culturable count for total bacteria is not to exceed $500 \mathrm{CFUs} / \mathrm{m}^{3}$ [15]. Meanwhile, the hospital was considered as a middle risk in which $50 \mathrm{CFUs} / \mathrm{m}^{3}$ identified an acceptable microbiological quality in the operative areas [16].

The objective of this study is to calculate the number of colony as CFU $/ \mathrm{m}^{3}$ on two cultivated media, RBCA and SDA and to identify the types of colonies grows on the respective media through their specific colour, and morphology. This study is in line with the study by Yassin and Almouqatea [1], which state that the growth behavior and patterns on different agar need to be evaluated.

\section{Study sites}

\section{Materials and Methods}

Sampling was performed in eight selected rooms in the Hospital Sultanah Nur Zahirah (HSNZ) namely washing room, endoscopy room, isolation $\mathrm{C}$ (haemodialysis unit), isolation B (haemodialysis unit), CAPD room, ward 7A, and negative pressure room.

\section{Media}

Media used for sampling included RBCA and SDA (Hi Media Company Limited, India). Sabouraud Dextrose Agar consist of peptone $10 \mathrm{gl}^{-1}$, glucose $40 \mathrm{gl}^{-1}$, agar $15 \mathrm{gl}^{-1}$ and Rose Bengal Chloramphenicol Agar consist of agar 15.5 $\mathrm{gl}^{-1}$, chloramphenicol $0.1 \mathrm{gl}^{-1}$, dextrose $10 \mathrm{gl}^{-1}$, magnesium sulfate $0.5 \mathrm{gl}^{-1}$, monopotassium phosphate $1 \mathrm{gl}{ }^{-1}$, mycological peptone $5 \mathrm{gl}^{-1}$ and rose bengal $0.05 \mathrm{gl}^{-1}$ were prepared.

\section{Sampling procedure}

Air was sampled using a MAS-100 Microbial Air Sampler (Merck) for standard $90 \mathrm{~mm}$ petri dishes which contain Rose Bengal Chloramphenicol Agar (RBCA, Merck) and Sabouraud Dextrose Agar (SDA) to collect air sample. The microbial air sampler was located at a height of about $1.1 \mathrm{~m}$ to $1.5 \mathrm{~m}$ from the floor of the sampling sites to simulate location of the breathing zone of a seated person [9,17]. The air sampler was sterilised with $70 \%$ ethanol before using. Air sampling was taken for $5 \mathrm{~min}$ at an airflow rate of $28.3 \mathrm{~L} / \mathrm{min}$. Duplicates of each plate were used 
in each stations. After the sampling, the petri dishes contained RBCA and SDA were incubated in an inverted position for a period of 3 to 7 days at room temperature $\left(25-27{ }^{\circ} \mathrm{C}\right)$ as per standard procedures $[18,19]$. After the desired duration of agar incubation, the colonies formed on each plates were counted and the counts obtained were averaged. According to the standard conversion table for accounting particles at single impaction sites, the transformed colony forming units (CFU) appeared to be similar to the original counted which were expressed in $\mathrm{CFU} / \mathrm{m}^{3}[17]$.

\section{Identification of fungi and bacteria}

Isolates with different colony morphologies were selected from RBCA and SDA for identification. A stereoscopic light microscope with a magnification of 40x and 100x was used for identification of the fungi and bacteria. The fungi and bacteria were identified due to their typical colony and morphology characters based on [18, 20-23].

\section{Results and Discussion}

The levels of occurrence of the bacteria and fungi identified in the indoor air from eight different rooms in the hospital are represented in Tables 1 and 2. As stated from Table 1 and Table 2, the high CFU $/ \mathrm{m}^{3}$ is found after incubation of 7 days which this is the optimum time different species need to grow. Additionally, the trend of growth of colony counts illustrated that as times increases there is progressively more time for microbial to divide new cells. In this study, it shows that longer incubation times were associated with the highest CFU count obtained in the washing room and reprocessing room which were $38 \mathrm{CFU} / \mathrm{m}^{3}$ and $149 \mathrm{CFU} / \mathrm{m}^{3}$ respectively. On the other hand, negative pressure room can be classified as a clean area but there also has a growth of colony on both media; RBCA media and SDA agar which the counts were $25 \mathrm{CFU} / \mathrm{m}^{3}$ and $11 \mathrm{CFU} / \mathrm{m}^{3}$ respectively. However, the values obtained for negative pressure room were within the acceptable levels of microbial count.

Table 1. Colony Forming Unit/Plate for RBCA Media

\begin{tabular}{|c|c|c|c|}
\hline Location/incubation & 3 days & 5 days & 7 days \\
\hline Washing room & $\begin{array}{l}1 \text { small pink colony } \\
27 \text { small white colonies } \\
1 \text { medium yellow colony }\end{array}$ & $\begin{array}{l}4 \text { small pink colonies } \\
12 \text { medium white colonies } \\
6 \text { medium yellow colonies } \\
8 \text { small black colonies }\end{array}$ & $\begin{array}{l}9 \text { small pink colonies } \\
15 \text { medium white colonies } \\
7 \text { medium yellow colonies } \\
7 \text { small black colonies }\end{array}$ \\
\hline Endoscopy room & $\begin{array}{l}2 \text { small pink colonies } \\
4 \text { small white colonies } \\
2 \text { small yellow colonies }\end{array}$ & $\begin{array}{l}3 \text { small black colonies } \\
7 \text { small white colonies } \\
2 \text { medium yellow colonies }\end{array}$ & $\begin{array}{l}7 \text { medium white colonies } \\
2 \text { medium yellow colonies } \\
7 \text { medium black colonies }\end{array}$ \\
\hline $\begin{array}{l}\text { Isolation C } \\
\text { (haemodialysis unit) }\end{array}$ & $\begin{array}{l}6 \text { small pink colonies } \\
11 \text { small white colonies } \\
2 \text { medium yellow colonies }\end{array}$ & $\begin{array}{l}8 \text { small pink colonies } \\
7 \text { small white colonies } \\
5 \text { medium yellow colonies } \\
11 \text { small black colonies }\end{array}$ & $\begin{array}{l}9 \text { small pink colonies } \\
8 \text { small white colonies } \\
6 \text { medium yellow colonies } \\
11 \text { medium black colonies }\end{array}$ \\
\hline $\begin{array}{l}\text { Isolation B } \\
\text { (haemodialysis unit) }\end{array}$ & 11 small white colonies & $\begin{array}{l}4 \text { small black colonies } \\
5 \text { medium white colonies } \\
6 \text { medium yellow colonies }\end{array}$ & $\begin{array}{l}5 \text { medium white colonies } \\
3 \text { medium yellow colonies } \\
8 \text { small black colonies }\end{array}$ \\
\hline $\begin{array}{l}\text { Reprocessing room } \\
\text { (haemodialysis unit) }\end{array}$ & $\begin{array}{l}27 \text { small white colonies } \\
3 \text { medium yellow colonies }\end{array}$ & $\begin{array}{l}9 \text { small black colonies } \\
10 \text { medium white colonies } \\
5 \text { medium yellow colonies } \\
3 \text { small orange colonies }\end{array}$ & $\begin{array}{l}1 \text { small pink colony } \\
9 \text { medium white colonies } \\
12 \text { medium yellow } \\
\text { colonies } \\
10 \text { medium black colonies }\end{array}$ \\
\hline
\end{tabular}


Che Noraini et al: A STUDY OF MICROBE AIR LEVELS IN SELECTED ROOMS OF A HOSPITAL CULTIVATED ON TWO CULTURE MEDIAS

Table 1 (cont'd). Colony Forming Unit/Plate for RBCA Media

\begin{tabular}{|c|c|c|c|}
\hline Location/incubation & 3 days & 5 days & 7 days \\
\hline CAPD room & $\begin{array}{l}4 \text { small pink colonies } \\
2 \text { small white colonies } \\
2 \text { medium yellow colonies }\end{array}$ & $\begin{array}{l}5 \text { small black colonies } \\
5 \text { small white colony } \\
3 \text { medium yellow colonies }\end{array}$ & $\begin{array}{l}4 \text { small pink colonies } \\
2 \text { small white colonies } \\
3 \text { medium yellow colonies } \\
6 \text { small black colonies }\end{array}$ \\
\hline Ward 7A & $\begin{array}{l}2 \text { small pink colonies } \\
8 \text { small white colonies } \\
1 \text { medium yellow colony }\end{array}$ & $\begin{array}{l}3 \text { small pink colonies } \\
10 \text { medium white colonies } \\
1 \text { medium black colony }\end{array}$ & $\begin{array}{l}3 \text { small pink colonies } \\
1 \text { small white colony } \\
9 \text { medium yellow colonies } \\
7 \text { small black colonies }\end{array}$ \\
\hline Negative pressure room & $\begin{array}{l}2 \text { small pink colonies } \\
9 \text { small white colonies } \\
2 \text { medium yellow colonies }\end{array}$ & $\begin{array}{l}1 \text { small pink colony } \\
14 \text { small white colonies } \\
3 \text { medium black colonies } \\
2 \text { small red colonies }\end{array}$ & $\begin{array}{l}2 \text { small pink colonies } \\
4 \text { small white colonies } \\
14 \text { medium yellow } \\
\text { colonies } \\
5 \text { small black colonies }\end{array}$ \\
\hline
\end{tabular}

Table 2. Colony Forming Unit/Plate for SDA Media

\begin{tabular}{|c|c|c|c|}
\hline Location/incubation & 3 days & 5 days & 7 days \\
\hline Washing room & $\begin{array}{l}3 \text { small black colonies } \\
2 \text { small white colonies } \\
2 \text { medium yellow colonies }\end{array}$ & $\begin{array}{l}3 \text { large black colonies } \\
5 \text { large white colonies } \\
2 \text { medium yellow } \\
\text { colonies }\end{array}$ & 2 big fungi colonies \\
\hline Endoscopy room & $\begin{array}{l}2 \text { small pink colonies } \\
14 \text { small white colonies } \\
3 \text { medium yellow colonies } \\
2 \text { small pink colonies } \\
16 \text { small orange colonies }\end{array}$ & $\begin{array}{l}6 \text { medium black colonies } \\
12 \text { large white colonies } \\
14 \text { medium yellow } \\
\text { colonies } \\
3 \text { medium orange } \\
\text { colonies }\end{array}$ & $\begin{array}{l}7 \text { medium grey colonies } \\
1 \text { large white colony }\end{array}$ \\
\hline $\begin{array}{l}\text { Isolation C } \\
\text { (hemodialysis unit) }\end{array}$ & $\begin{array}{l}3 \text { small black colonies } \\
55 \text { small white colonies }\end{array}$ & $\begin{array}{l}11 \text { medium black colonies } \\
18 \text { medium white } \\
\text { colonies } \\
3 \text { medium yellow } \\
\text { colonies }\end{array}$ & $\begin{array}{l}2 \text { fungi colonies } \\
6 \text { medium black colonies }\end{array}$ \\
\hline $\begin{array}{l}\text { Isolation B } \\
\text { (haemodialysis unit) }\end{array}$ & $\begin{array}{l}12 \text { small white colonies } \\
9 \text { medium black colonies }\end{array}$ & $\begin{array}{l}2 \text { large black colonies } \\
3 \text { medium white colonies } \\
3 \text { medium yellow } \\
\text { colonies } \\
5 \text { medium grey colonies }\end{array}$ & $\begin{array}{l}5 \text { medium grey colonies } \\
3 \text { medium white colonies } \\
2 \text { medium yellow } \\
\text { colonies } \\
1 \text { large black colony }\end{array}$ \\
\hline $\begin{array}{l}\text { Reprocessing room } \\
\text { (haemodialysis unit) }\end{array}$ & 129 small black colonies & $\begin{array}{l}135 \text { medium black } \\
\text { colonies }\end{array}$ & $\begin{array}{l}149 \text { medium black colony } \\
\text { 1large black colony }\end{array}$ \\
\hline
\end{tabular}


Table 2 (cont'd). Colony Forming Unit/Plate for SDA Media

\begin{tabular}{|c|c|c|c|}
\hline Location/incubation & 3 days & 5 days & 7 days \\
\hline CAPD room & $\begin{array}{l}1 \text { small orange colony } \\
21 \text { small white colonies } \\
1 \text { medium yellow colony }\end{array}$ & $\begin{array}{l}7 \text { medium black colonies } \\
14 \text { medium white } \\
\text { colonies } \\
3 \text { medium yellow } \\
\text { colonies }\end{array}$ & $\begin{array}{l}1 \text { large white colony } \\
4 \text { medium yellow } \\
\text { colonies } \\
6 \text { medium black colonies }\end{array}$ \\
\hline Ward 7A & $\begin{array}{l}2 \text { small black colonies } \\
20 \text { small white colonies } \\
8 \text { medium yellow colonies }\end{array}$ & $\begin{array}{l}3 \text { medium black colonies } \\
20 \text { medium white } \\
\text { colonies } \\
7 \text { medium yellow } \\
\text { colonies } \\
1 \text { large white colony }\end{array}$ & $\begin{array}{l}1 \text { medium grey colony } \\
21 \text { medium white } \\
\text { colonies } \\
8 \text { medium yellow } \\
\text { colonies } \\
5 \text { medium black colonies } \\
1 \text { small orange colony }\end{array}$ \\
\hline Negative pressure room & $\begin{array}{l}1 \text { large black colony } \\
15 \text { small white colonies } \\
2 \text { medium yellow colonies } \\
5 \text { small orange colonies }\end{array}$ & $\begin{array}{l}1 \text { medium black colony } \\
12 \text { medium white } \\
\text { colonies } \\
2 \text { medium yellow } \\
\text { colonies } \\
4 \text { medium grey colonies }\end{array}$ & $\begin{array}{l}5 \text { medium grey colonies } \\
6 \text { medium yellow } \\
\text { colonies } \\
1 \text { large black colony }\end{array}$ \\
\hline
\end{tabular}

In the present study the air quality of all of the selected rooms were found to be good, with acceptable values for the air microbial counts, since the microbial levels were lower than $50 \mathrm{CFU} / \mathrm{m}^{3}$ which in the range from $8-38 \mathrm{CFU} / \mathrm{m}^{3}$ for RBCA media and $2-149 \mathrm{CFU} / \mathrm{m}^{3}$ for SDA media except for the microbial level in reprocessing room of hemodialysis unit Figure 1.

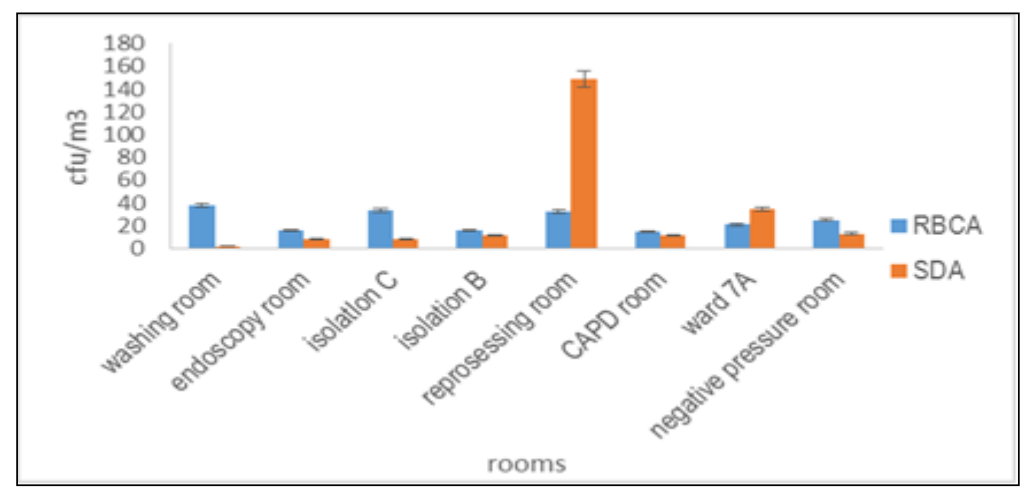

Figure 1. Mean value of microbial counts in each room for RBCA media and SDA media

In this experiment the plates were incubated for a distinct period of time. Figure 2 shows RBCA agar after three, five and seven days of incubation. After incubating the plate, a variety of organism species are grown with increasing times of days of incubation. In this study, it shows that average numbers of fungi on RBCA media was the highest in washing room because it is the place where chemicals most widely used for the purposes of washing medical apparatus before and after operation and preparation for the operation procedures. Figure 3 shows SDA 
agar plate after three, five and seven days of the air sampling in reprocessing room. The reprocessing room at hemodialysis unit shows the highest number of colony. The viable cells counted in the reprocessing room and washing room were significantly higher than those found in other rooms because of inadequate ventilation and air filtration system in those rooms.
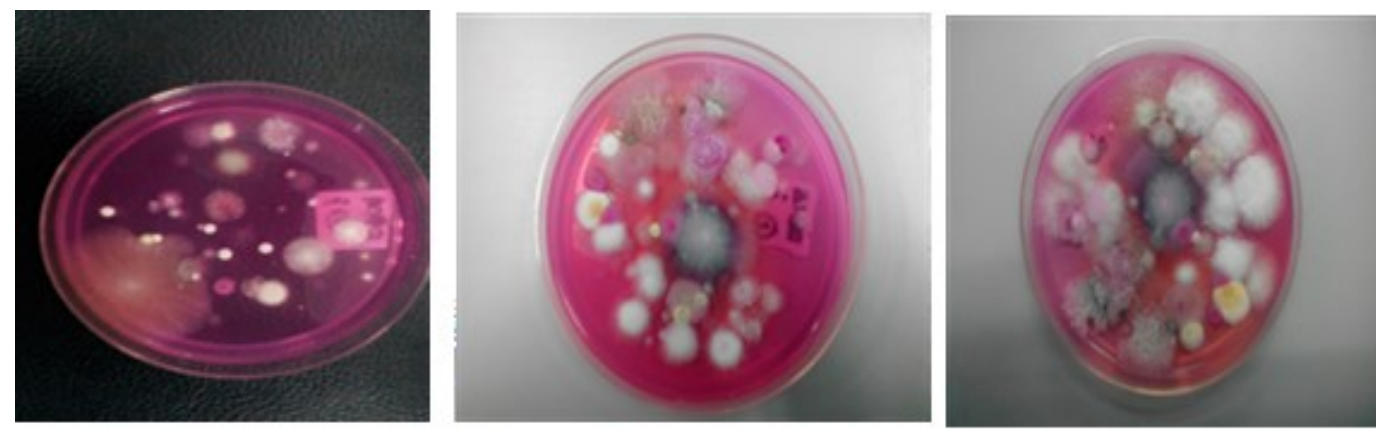

Figure 2. RBCA agar plate after 3,5 and 7 days of the air sampling in washing room (the highest concentration of fungi on RBCA) of the hospital HSNZ
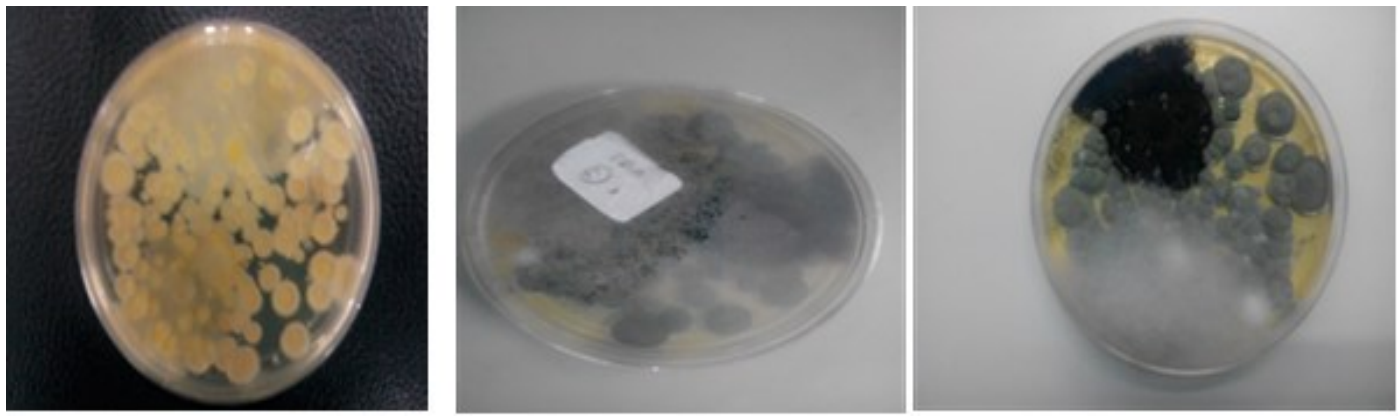

Figure 3. SDA agar plate after 3, 5 and 7 days of the air sampling in reprocessing room (hemodialysis unit) (the highest concentration of fungi on SDA) of the hospital HSNZ

In the present study, totally five different fungi were collected. The most dominant fungi were identified as Cladosporium sp. (85\%), Penicillium sp. (48\%), yeast sp. (28\%), Mucor sp. (25\%), and Aspergillus sp. (12\%). This indicated that indoor environment of each selected location in the hospital provides more favorable conditions for the survival of fungi. In addition, chloramphenicol used in RBCA media was included for the elimination of bacterial colonies in fungal culture while rose Bengal reduced the growth of fungi which eased identification of individual colonies [24]. This result is in line with the finding of earlier researcher by Guiamet et al. [25], who studied in indoor air sampling showed the similar identification of fungi that were Aspergillus sp. and Penicillium sp. as the most abundant microorganisms because of the microbes can be easily cultivated in the indoor environments.

\section{Conclusion}

The current study clearly indicates that there have a growth of airborne fungi and bacteria on two cultivated medias in the hospital even the room environment is clean. Bacteria show higher growth on SDA media while slow growing of fungi on RBCA media. The use of RBCA rather than SDA significantly improved the fungal yield. The lowest detection level of the colony counts was calculated as $2 \mathrm{CFU} / \mathrm{m}^{3}$ in washing room while the highest detection level of the colony counts was calculated as $149 \mathrm{CFUs} / \mathrm{m}^{3}$ in reprocessing room of hemodialysis unit respectively. 
The evaluation of colony counts in the hospital rooms provides a continuous control for airborne microbial growth and it is important to identify the level of bacterial and fungal in the hospital work environment over the time for the health reassurance of patients and hospital team.

\section{Acknowledgement}

The authors are grateful to the Director and staffs of the hospital where fieldwork was undertaken for their cooperation during this study. The first author would like to thank Ministry of Higher Education for the My Brain 15 scholarship that has been given to support this research study. The first author would also like to acknowledge East Coast Environmental Research Institute (ESERI) for providing research facilities.

\section{References}

1. Yassin, M. F. and Almouqatea, S. (2010). Assessment of airborne bacteria and fungi in an indoor and outdoor environment. International Journal of Environmental Science Technology, 7 (3): 535 - 544.

2. US Environmental Protection Agency (2003). An office building occupant's guide to indoor air quality. Indoor air quality publications.

3. Mentese, S., Arisoy, M., Rad, A. Y. and Gullu, G. (2009). Bacteria and fungi levels in various indoor and outdoor environments in Ankara, Turkey. Clean, 37(6): 487 - 493.

4. Wu, M-J., Feng, Y-S, Sung, W-P. and Surampalli, R. Y. (2011). Quantification and analysis of airborne bacterial characteristics in a nursing care institution. Air \& Waste Management, 61: 732 - 739.

5. Sunesson, A-L., Vaes, W. H. J., Nilsson, C-A., Blomquist, G., Andersson, B. and Carlson, R. (1995). Identification of volatile metabolites from five fungal species cultivated on two media. Applied Environmental Microbiology, 61(8): 2911 - 2918.

6. Gorny, R. L., Reponen, T., Willeke, K., Schmechel, D., Robine, E., Boissier, M. and Grinshpun, S. A. (2002). Fungal fragments as indoor air biocontaminants. Applied Environmental Microbiology, 68(7): 3522 - 3531.

7. Fracchia, L., Pietronave, S., Rinaldi, M. and Martinotti, M. G. (2006). The assessment of airborne bacterial contamination in three composting plants revealed site-related biological hazard and seasonal variations. Journal of Applied Microbiology, 100(5): 973 - 984.

8. Brodie, E. L, De Santis, T. Z., Parker, J. P., Zubietta, I. X., Piceno, Y. M. and Andersen, G. L. (2007). Urban aerosols harbor diverse and dynamic bacterial populations. Proceedings of the National Academy of Sciences USA, 104(1): 299 - 304.

9. Wang, X., Bi, X., Sheng, G. and Fu, J. (2006). Hospital indoor $\mathrm{PM}_{10} / \mathrm{PM}_{2.5}$ and associated trace elements in Guangzhou, China. Science of the Total Environment, 366: 124 - 135.

10. Pasanen, A. L., Lappalainen, S. and Pasanen, P. (1996). Volatile organic metabolites associated with some toxic fungi and their mycotoxins. Analyst, 121: $1949-1953$.

11. Pitkaranta, M., Meklin, T., Hyvarinen, A., Nevalainen, A., Paulin, L., Auvinen, P. E. Lignell, U. and Rintala, H. (2011). Molecular profiling of fungal communities in moisture damaged buildings before and after remediation - a comparison of culture-dependent and culture-independent method. Bio Med Central Microbiology. 11: 235.

12. Harrel, S. K. and Molinari, J. (2004). Aerosols and splatter in dentistry: A brief review of the literature and infection control implications. Journal of American Dental Association, 135: 429 - 437.

13. Manarte-Montiro, P., Carvalho, A., Pina, C., Oliveira, H. and Manso, M. C. (2013). Air quality assessment during dental practice: Aerosols bacteria counts in an universitary clinic. Revista Portuguesa de Estamatologia Medicina Dentaria Cirurgia Maxilofacial, 54(1): 2 - 7.

14. Pasquarella, C., Pitzurra, O. and Savino, A. (2000). The index of microbial air contamination. Journal of Hospital Infection, 46: $241-256$.

15. Jense, P. A. and Schafer, M. P. (1998). Sampling and characterization of bioaerosol. NIOSH Manual of Analytical Methods, 1(15): 82 - 112.

16. Cellini, L., Di Campli, E., Di Candia, M. and Chiavaroli, G. (2001). Quantitative microbial monitoring in a dental office. Public Health, 115: 301 - 305.

17. Rajasekar, A. and Balasubramaniam, R. (2011). Assessment of airborne bacteria and fungi in food courts. Building and Environment, 46: 2081 - 2087.

18. Barnett, H. L. and Hunter, B. B. (1999). Illustrated genera of imperfect fungi. $4^{\text {th }}$ Edition, American Phytopathological Society, St. Paul, Minnesota.

19. Suerdem, T. B. and Yildirim, I. (2009). Fungi in the atmospheric air of Canakkale province in Turkey. African 
Journal of Biotechnology, 8(18): 4450 - 4458.

20. Pitt, I. J. and Hocking, D. A. (1985). Fungi and food spoilage. Academic Press, London.

21. Pitt, I. J. (2000). A laboratory guide to common Penicillium species. $3^{\text {rd }}$ Edition. North Ryde, N.S.W., Australia.

22. Klich, M. A. (2002). Identification of common Aspergillus Species. 1st Edition. Utrecht, The Netherlands.

23. Watanabe, T. (2002). Soil and seed fungi. In morphologies of cultured fungi and key to species. Lewis Publishers, Boca Raton, Boston, London, Washington D.C

24. Goh, I., Obbard, J. P., Viswanathan, S. and Huang, Y. (2000). Airborne bacterial and fungal spores in the indoor environment: a case study in Singapore. Acta Biotechnologica, 20: 67 - 73.

25. Guiamet, P. S., Rosato V., Saravia, S. G., Garcia, A. M. and Moreno, D. A. (2012). Biofouling of crypts of historical and architectural interest at La Plata Cemetery (Argentina). Journal of Cultural Heritage, 13: 339 344. 